\title{
Herbage mass and chemical composition of the heterogeneous grasslands affected by harvesting time in Subtropical terrain Nepal
}

\author{
Prabin Pandey ${ }^{1}$, Tej Narayan Bhusal ${ }^{2}$, Thaneshwar Pandey ${ }^{3}$, Surya Prasad Sharma ${ }^{4}$, Badrika \\ Devkota-Barsila $^{5}$ and Shanker Raj Barsila ${ }^{6, *}$ \\ ${ }^{1}$ Institute of Agriculture and Animal Science, Tribhuvan University,Kathmandu, Nepal \\ ${ }^{2}$ Agriculture and Forestry University, Faculty of Agriculture, Rampur, Chitwan, Nepal \\ ${ }^{3}$ Institute of Agriculture and Animal Science, Paklihawa Campus, Tribhuvan University, Rupandehi, \\ Nepal \\ ${ }^{4}$ Institute of Agriculture and Animal Science, Lamjung Campus, Tribhuvan University, Lamjung, \\ Nepal \\ ${ }^{5}$ Multi-Dimensional Action for Development, Bharatpur Metropilitan-19, Chitwan, Nepal \\ ${ }^{6}$ Agriculture and Forestry University, Department of Animal Nutrition and Fodder Production, \\ Rampur, Chitwan, Nepal. \\ *Corresponding author: srbarsila@afu.edu.np; ORCID ID: https://orcid.org/0000-0001-6840-1503. \\ Received: August 07; Accepted: September 19; Published: October 25, 2019 \\ (C) Copyright: Pandey et al. (2019).
}

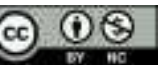
International License.

\begin{abstract}
A study was carried out to evaluate the productivity and chemical composition of heterogeneous grasslands at Agriculture and Forestry University (AFU) livestock farm. The four grassland ecotypes were chosen as upland north, upland south, lowland south and lowland north. The dominating herbage species and cover abundance by the botanical groups were studied on day before the harvesting. Later, the herbage dry matter productivity was estimated by quadrat cutting during May and June, 2017. Chemical analysis was done by using the proximate method for dry matter (DM), crude protein (CP), crude fiber (CF) and ether extract (EE) content. Research results showed that the AFU grassland dominated by perennial grasses and sedges followed by the forbs. The mean coverage of grasses and sedges was about 55\%, whilst that of forbs was about $29 \%$ and the least was for legumes (about 4\%). The cumulative herbage mass was about $1.53 \mathrm{t} / \mathrm{ha}$ on the DM basis, whilst the highest DM was found in the upland-south $(1.74 \mathrm{t} / \mathrm{ha})$ and the least was in the upland-north $(1.334 \mathrm{t} / \mathrm{ha})$. The proximate analysis further revealed that the site had no effect on CF content, whilst the CP was significant only at the second harvest for the lowland north $(8.34 \%)$. Data revealed that the herbage composition might depend upon the soil moisture availability and geographical aspect. The dominance of perennial grasses at AFU grasslands revealed the yield stability, but needs the improvement through inoculation with leguminous forages for improved feed quality.
\end{abstract}

Keywords: Herbage cover, herbage mass, proximate composition, rangeland, species dominance, Vegetation ecotypes.

Correct citation: Pandey, P., Bhusal, T. N., Pandey, T., Sharma, S.P., Devkota-Barsila, B., \& Barsila, S.R. (2019). Herbage mass and chemical composition of the heterogeneous grasslands affected by harvesting time in Subtropical terrain Nepal. Journal of Agriculture and Natural Resources, 2(1), 135-144. DOI:https://doi.org/10.3126/janr.v2i1.26055 
Journal of Agriculture and Natural Resources (2019) 1(1): 135-144

ISSN: 2661-6270 (Print), ISSN: 2661-6289 (Online)

DOI:https://doi.org/10.3126/janr.v2i1.26055

\section{INTRODUCTION}

The grasslands or pasturelands are important components in agricultural production systems, by providing feed for livestock and by replenishing soil organic matter, preventing soil erosion and restoring soil fertility and so on (Fageria et al., 2010). The management for longterm sustainability of such lands often requires the contribution of short-term activities (Snyman, 1998), such as herbage species mix, moisture etc. The Pasture productivity and nutritive value are major factors that determine patterns of grazing distribution of livestock (Bailey et al., 1996), and herbage harvested for also the feeding of animals in the tie stalls. The aboveground herbage mass productivity and measures of nutritive value, vary between years and between the physiological stages within a given growing season at harvest (Givens et al., 1993; Beecher et al., 2015) and it may further vary upon the various grassland eco-types favored by different other biotic and abiotic factors (Snyman et al., 1993), and geographical aspects (Radcliffe, 1982; Bennie et al., 2006) and etc. The present study aimed at exploring the differences in herbage dry matter productivity and chemical composition at two harvesting regimen in tfour different grassland ecotypes in subtropical conditions of a close distant at Agriculture and Forestry University livestock farm

\section{MATERIALS AND METHODS}

\section{Site selection and layout}

The current experimental set up (study area) was located inside the Agriculture and Forestry University, Rampur, Chitwan, Nepal. It lies at a latitude of $27^{0} 3814.1^{\prime \prime} \mathrm{N}$ and longitude $84^{0} 2125.2$ E (NMRC, 2017). Study area was located at an altitude of $257 \mathrm{~m}$ from the sea level. The experimental site had a humid and sub-tropical with cool winter climate $\left(2\right.$ to $\left.3^{\circ} \mathrm{C}\right)$ and hot summer days $\left(43^{\circ} \mathrm{C}\right)$. The annual rainfall was $1500 \mathrm{~mm}$, where monsoon period (about 75\% of annual rainfall) started from mid-June to mid-September (NMRC, 2017).

The study area had about 120 ha land occupied by native perennial species and about onethird of which was in lowland category. The selected sites had a mix mosaic of perennial vegetation. The four experimental sites; each having five blocks of $0.5 \times 0.5$ square meter served as the replicated sampling units for herbage mass productivity and forage samples for laboratory analysis.

Based on the water submergence (water visibility) and geographical aspect( north/south), the study grasslands were classified into broad four broad sites as upland north, upland south, lowland south and lowland respectively.

\section{Herbage cover estimation}

The herbage species dominance and botanical coverage were studied the day before the cutting or herbage sampling. Grasses, forbs, legumes, grass-like plants (sedges/cyperus) and bare patchiness were studied over the grassland to determine plan cover by following Gibbens and Beck (1987). Simple bird's eye view method was used to measure the basal cover of each species and herbage species score was set from 0-100 from low to high abundance (basal cover). Identification of plant species was further completed. Five the most dominated plant species over the selected grasslands types were identified and presented in the present study. Later, the herbage cover of the botanical groups was recalculated.

\section{Herbage sampling}


Journal of Agriculture and Natural Resources (2019) 1(1): 135-144

ISSN: 2661-6270 (Print), ISSN: 2661-6289 (Online)

DOI:https://doi.org/10.3126/janr.v2i1.26055

Two cuttings were taken in the one-month interval during summer (May and June) at each experimental block of the grassland eco-types. At each site, five fixed plots $\left(0.5 \times 0.5 \mathrm{~m}^{2}\right)$ were chosen randomly and fenced prior to herbage growth in April 2017. Sampling bag was labeled with a time of sampling and sites details from where it was taken. The vegetation covered by a quadrat frame $0.5 \times 0.5 \mathrm{~m}^{2}$ was cut above $2 \mathrm{~cm}$ from the ground to mimic the general removal of vegetation by grazing cattle and buffaloes. Debris (dead matter) was avoided in the sample for subjecting to laboratory analysis. Fresh weight of herbage was weighted in the field by a digital balance (Ohaus $\operatorname{Pro}^{\mathrm{TM}}$ ). Plant identification and herbage cover estimation were conducted in the field during the cover estimates.

\section{Herbage mass estimation}

Herbage mass was estimated by cutting, drying and weighing the aboveground herbages. The green herbage mass was weighed on-site. Five quadrats-cut from each site were collected in well-labeled bags. Quadrat with the size of $0.5 \times 0.5 \mathrm{~m}^{2}$ was used for this purpose. Grass shoots were harvested above $2 \mathrm{~cm}$ from the ground assuming the available height of plant grazed by cattle and buffaloes.

\section{Laboratory analysis}

The laboratory activities were performed at Agriculture and Forestry University (AFU) animal nutrition laboratory. The harvested materials were dried to a constant temperature of $65^{\circ} \mathrm{C}$ in the oven at 48 hours and weighed to determine total dry matter productivity and The chemical composition of herbage samples was estimated by following the guidelines of the AOAC (1991).The crude protein content in samples was estimated by using the macroKjeldahl method, in which digestion, distillation, and titration were done. Later, the total ash content was determined for a $2 \mathrm{~g}$ dried milled (by Thomas Mill, $45 \mathrm{~mm}$ mesh size) of sample putting in a muffle furnace at $550{ }^{\circ} \mathrm{C}$ for eight hours. The Crude fiber was determined by washing a sample with acid and base in presence of heat and subtracting final weight with total ash content using the Gold Fish apparatus. A dried sample ( $2 \mathrm{~g})$ was extracted with petroleum ether in Soxhlet Apparatus to remove the ether-soluble component present in it. Then, the extracted material was dried to a constant weight in an oven at $65^{\circ} \mathrm{C}$ for $48 \mathrm{hr}$. and the obtained weight was the fat content of the sample.

\section{Data analysis}

For data analysis, GenStat release version 11 (Payne et al., 2011) was used to analyze the data. The simple descriptive statistics were employed i.e. for herbage cover estimates. The following one way analysis of variance (ANOVA) model. The means were compared in terms herbage mass productivity and major chemical composition using the least significant difference (LSD) at 5\% level of significance (Jan et al., 2009; Baral et al., 2016; Shrestha, 2019; Sharma et al., 2016; Kandel \& Shrestha, 2019).

$\mathrm{Y}_{\mathrm{ijk}}=\mu+\mathrm{h}_{\mathrm{j}}+\mathrm{e}_{\mathrm{ijk}}$ Equation (1).

Where, $Y_{\mathrm{ijk}}=$ output of individual observation for parameter

$\mu=$ Over all mean for parameter $Y$

$\mathrm{s}_{\mathrm{i}}=$ Fixed effect of the $i^{\text {th }}$ parameter

$\mathrm{e}_{\mathrm{ijk}}=$ Residual error 
Journal of Agriculture and Natural Resources (2019) 1(1): 135-144

ISSN: 2661-6270 (Print), ISSN: 2661-6289 (Online)

DOI:https://doi.org/10.3126/janr.v2i1.26055

\section{RESULTS AND DISCUSSION}

\section{Dominated plant species in four sites}

In the southern upland sites, the mosaic of Cynodon-Eleusine-Cyperus was dominated, whilst in the northern uplands, the herbage mosaic of Cynodon-Imperata-Cyperus was dominated. The scale of dominance of top five species in both of the upland sites has been shown in detail in Table1.

Table 1. Dominated herbage species over an upland area

\begin{tabular}{|c|c|c|c|}
\hline \multicolumn{3}{|c|}{ Upland South } & \multirow{2}{*}{$\begin{array}{l}\text { Upland north } \\
\text { Score }\end{array}$} \\
\hline Plant species & Score & Plant species & \\
\hline Cynodon dactylon & 10 & Cynodon dactylon & 9 \\
\hline Elucine indica & 9.5 & Imperata cylindrica & 8.5 \\
\hline Cyperus rotundus & 6.5 & Cyperus rotundus & 6 \\
\hline Imperata cylindrica & 6 & Elucine indica & 5.5 \\
\hline Mimosa pudica & 5 & Xanthium strumarium & 3 \\
\hline
\end{tabular}

Likewise in the southern lowland sites, the species combination of Furena-CyanodonDigitaria was dominated, whilst the Persicaria-Rotala-Xanthium mix was dominated (table 2).

Table 2. Dominated herbage species in the lowlands.

\begin{tabular}{lclc}
\hline & Lowland south & Lowland north \\
\hline Plant species & Score & Plant species & Score \\
\hline Furena umbellate & 10 & Persicaria barbata & 10 \\
Cyanodon dactylon & 10 & Rotala rotundifolia & 9.5 \\
Digitaria sanguinalis & 9.5 & Xanthium strumarium & 8 \\
Cyperus rotundus & 9 & Alternanthera sessilis & 6 \\
Commelia diffusa & 5.5 & Ageratum houstonianum & 4.5 \\
\hline
\end{tabular}

Note:A score of 0-10 was used (Scores based on USDA Forest Service Method).

Cynodon dactylon, Eleusine indica and grass-like plants (cyperus) were found in all sites. Other grass species found in those areas were Amannia baccifera, Amannia baccifera, Smithia sensitive, Bidens Pilosa, Dysophylla auricularia, Bidens Pilosa, Smithia sensitive, Youngia japonica, Isachne globosa, Digitaria sangninalis, Eragrostis variabilis, Blumea lacera, Alternanthera sessilis, Phyllanthus urinaria etc. in upland and Eleucine indica, Pteris vittata, Ptris vittata, Justicia diffusa, Lindernia crustacean, Lindernia crustacean, Xanthium strumarium etc. in lowland. These indicated greater plant species diversity in grassland and an indication of grassland stability and higher primary productivity as reported by Daly et al., (1996) and Caldeira et al. (2001). Chaudhary and Devkota (2018) also reported grasses as predominant in rangelands whereas the proportion of legume was minimum in the subtropical grasslands as in the present study. 
Journal of Agriculture and Natural Resources (2019) 1(1): 135-144

ISSN: 2661-6270 (Print), ISSN: 2661-6289 (Online)

DOI:https://doi.org/10.3126/janr.v2i1.26055

The occurrence of vegetative life form varied greatly among the grasslands ecotypes (Table 3). Upland north had the highest (47.5\%) and lowland south had the lowest (37\%) cover of grasses. Broadleaf herbage cover was highest in the upland north $(33.4 \%)$ followed by lowland south (32.7\%). Cover by legume was only with an average of 1.5 to $6 \%$ of basal cover. The cyperus or sedges were the highest in the upland south (19.3\%) followed by lowland south $(11.6 \%)$ and lowland north $(9.4 \%)$. The herbage cover occupied by dead matter was only less than $4 \%$ across the experimental sites studied. The highest bare patchiness (open) was found in the upland south (10.7\%) and lowest in Lowland south (7.8\%) respectively. The detail of the herbage cover by the botanical groups has been presented in table 3.

Table 3.Percentage herbage cover in different rangeland types by botanical groups

\begin{tabular}{lcccccc}
\hline Range category & Grass & Forb & Legume & Grass-like & Dead matter & Bare patchiness \\
\hline Upland north & 47.5 & 33.4 & 1.5 & 6.9 & 3.0 & 10.7 \\
Lowland north & 42.0 & 27.0 & 6.0 & 9.40 & 3.2 & 9.2 \\
Upland south & 43.8 & 24.4 & 2.5 & 19.30 & 2.8 & 8.4 \\
Lowland south & 37.0 & 32.7 & 4.5 & 11.6 & 3.2 & 7.8 \\
\hline Mean & 42.6 & 29.4 & 3.62 & 11.8 & 3.1 & 9.0 \\
SEM & 15.9 & 16.1 & 16.0 & 9.3 & 4.5 & 3.4 \\
\hline
\end{tabular}

Note: SEM $=$ Standard error of mean.

Taking into account the herbage cover at all the study sites together, there were much more abundance of grasses than any forbs or grass-like plants (cyperus) and legumes respectively. However, the occurrence of each botanical group varied greatly among the grassland types. The existence of variation in the frequency of botanical groups, particularly in the proportion of perennials may show a variation in stocking rates or nature of soil or a combination of the both. It has been repeatedly reported that grasslands are ecologically favored when perennials dominate the ecosystem.

\section{Herbage mass productivity}

The weight of herbage harvested and their respective dry weights were given in table 4 . Site had significant contribution to the cumulative dry weight mass $(\mathrm{P}<0.05)$. The highest cumulative dry weight mass was observed at the upland south $(1.738 \mathrm{t} / \mathrm{ha})$ and the lowest in the upland north (1.338 t/ha), whereas it remained within the range of about $1.5 \mathrm{t} / \mathrm{ha}$ in other two sites. At first harvest, the harvesting time had no significant effect to herbage mass, whilst it was found significant at second harvest. Total fresh herbage yield in the first harvest was obtained $1768 \mathrm{~kg} / \mathrm{ha}$ to $3212 \mathrm{~kg} / \mathrm{ha}$ in first harvest and $2540 \mathrm{~kg} / \mathrm{ha}$ to $4124 \mathrm{~kg} / \mathrm{ha}$ in second harvest from this study (fresh mass data not presented here), which is concomitant to the reports of Pariyar (1998) and Pandey (2007) who estimated the total forage yield of tropical grassland of Nepal upto $4000 \mathrm{~kg} / \mathrm{ha}$.

Table 4. Green and dry weight of herbage with their respective cumulative weight.

Range type

Harvesting time

Accumulated dry weight, t/ha

$1^{\text {st }}$ May 1 st June


Journal of Agriculture and Natural Resources (2019) 1(1): 135-144

ISSN: 2661-6270 (Print), ISSN: 2661-6289 (Online)

DOI:https://doi.org/10.3126/janr.v2i1.26055

\begin{tabular}{|c|c|c|c|}
\hline Upland North & 0.580 & $0.760^{\mathrm{b}}$ & $1.338^{\mathrm{b}}$ \\
\hline Lowland north & 0.721 & $0.860^{\mathrm{ab}}$ & $1.583^{\mathrm{ab}}$ \\
\hline Upland South & 0.521 & $1.220^{\mathrm{a}}$ & $1.738^{\mathrm{a}}$ \\
\hline Lowland south & 0.604 & $0.850^{\mathrm{b}}$ & $1.45^{\mathrm{ab}}$ \\
\hline Mean & 0.607 & 0.921 & 1.527 \\
\hline SEM $( \pm)$ & 0.065 & 0.057 & 0.122 \\
\hline $\mathrm{CV}(\%)$ & 0.239 & 0.137 & 0.376 \\
\hline $\operatorname{LSD}_{(0.05)}$ & NS & $0.174 *$ & 2.59 \\
\hline
\end{tabular}

Note: SEM $=$ Standard error of mean, $C V=$ Coefficient of variation, $L S D=$ Least significant difference. $*$ indicated probability $p<0.05$.

Production and productivity of the grasslands, however, vary from $0.65 \mathrm{MT} \mathrm{DM} / \mathrm{ha} / \mathrm{yr}$. to 3.60 MT DM/ha/yr. in different agro-ecological zones (LMP, 1993; Pariyar, 1998). Dry matter yield of grasses in the current study was within the range of $0.521 \mathrm{t}$ to 0.721 t/ha in first harvest and $0.76 \mathrm{t} / \mathrm{ha}$ to $0.122 \mathrm{t} / \mathrm{ha}$ in the second harvest. The practical reasons associated to the lower herbage productivity in the first harvest might be due to the low rainfall as compared to the second harvest (Austin, 2002), that constrained the low soil moisture (Fay et al., 2003). It has been repeatedly stated in previous experiments that the perennial species productivity is associated with the seasonal rainfall (Cable, 1975; Fynn and O'Connor, 2000) and their richness (Sanderson et al., 2005). However, the study on effect soil factors on dry matter productivity were lacking in the present study.

\section{Herbage chemical composition}

The result of the chemical composition of grasses harvested from the study areas was presented in Table 5. Grass collected from grasslands was no difference $(p<0.05)$ in levels of $\mathrm{EE}, \mathrm{CF}$ and Ash content in all four sites. The protein content of different sites was slightly different. The protein content of herbage at first harvest was found no difference but protein content of herbage at second harvest was found significantly different in four sites. In the first harvest, lowland south was highest in protein content with $8.78 \%$ followed by upland north $(7.76 \%)$ and upland south $(7.7 \%)$. In the second harvest; lowland north was richest in protein content with $8.34 \%$ followed by upland south $(7.96 \%)$ and lowland south $(6.9 \%)$. Protein content was found highest in the first harvest. Mean crude fiber content of herbage was $29.22 \%$ in first harvest and $29.85 \%$ in the second harvest. Ether extract in all sites were not more than $4 \%$ of the dry matter. Average ash content of the herbage was $6.49 \%$ in first harvest and $6.82 \%$ in the second harvest.

Crude protein value ranged between 6.4 and $9.8 \%$ and showed an average of $8.9 \%$ in first harvest and $8.2 \%$ in the second harvest among the grasslands. This showed a low protein value of grassland. Daily protein requirements for ruminant could be expressed as $10.7 \%$ of dry matter intake or at least $13.5 \%$ to $14.5 \%$ crude protein is required for high producing dairy cows. Lower protein value was due to the poor richness of leguminous herbages. The protein content of herbage at first harvest was greater than that of the second harvest. 
Journal of Agriculture and Natural Resources (2019) 1(1): 135-144

ISSN: 2661-6270 (Print), ISSN: 2661-6289 (Online)

DOI:https://doi.org/10.3126/janr.v2i1.26055

Table 5. Chemical composition of the herbages harvested at different grassland eco-types at AFU livestock farm

\begin{tabular}{|c|c|c|c|c|c|c|c|c|}
\hline \multirow[b]{2}{*}{ Range category } & \multicolumn{4}{|c|}{ First harvest (\%) } & \multicolumn{4}{|c|}{ Second harvest $(\%)$} \\
\hline & $\mathrm{CP}$ & $\mathrm{CF}$ & $\mathrm{EE}$ & Ash & $\mathrm{CP}$ & $\mathrm{CF}$ & $\mathrm{EE}$ & Ash \\
\hline Upland north & 7.76 & 29.42 & 3.04 & 6.76 & $5.44^{\mathrm{b}}$ & 29.82 & 2.78 & 6.78 \\
\hline Lowland north & 7.50 & 29.18 & 3.0 & 6.28 & $8.34^{\mathrm{a}}$ & 29.7 & 2.92 & 6.84 \\
\hline Upland south & 7.70 & 29.32 & 2.92 & 6.54 & $7.96^{\mathrm{ab}}$ & 30.1 & 2.82 & 6.82 \\
\hline Lowland south & 8.78 & 28.94 & 3.08 & 6.38 & $6.9^{\mathrm{ab}}$ & 29.76 & 2.82 & 6.84 \\
\hline Mean & 8.94 & 29.22 & 3.02 & 6.49 & 8.16 & 29.85 & 2.84 & 6.82 \\
\hline$p$-value & 0.87 & 0.79 & 0.22 & 0.33 & $0.04 *$ & 0.65 & 0.74 & 0.99 \\
\hline $\operatorname{SEM}( \pm)$ & 1.25 & 0.35 & 0.05 & 0.19 & 0.87 & 0.24 & 0.09 & 0.22 \\
\hline CV (\%) & 28.03 & 2.68 & 3.9 & 6.43 & 21.31 & 1.76 & 7.23 & 7.06 \\
\hline
\end{tabular}

It revealed that protein content of plant was decreased in subsequent harvesting in response to increasing the fiber content. But the $\mathrm{CP}$ content of herbage was low indicating that grazing only to supply required nutrition for the animals. The CP content in the present study was approximately in the range as reported by Chaudhary and Devkota (2018) which was 7.04$11.1 \%$ during post-monsoon and 8.4-11.4\% during the start of winter. Tiwari (2005) estimated $21.9 \%, 12.13 \%$, and $12 \%$ respectively for average dry matter, total ash and crude protein content of different grass species while studied 686 samples of different grass species collected from 28 districts of Nepal. Yield performance of animals raised by grazing depends on the nutrient content of the species present in grassland. Palatability of plants, one of the factor for species selection by animals, is positively correlated with the high soluble cell components. Therefore, grassland having plant species low in lignin and cellulose content is more preferable for grazing of animals to obtain better yield

performance. In addition, the crude protein content has minor variation in upland and lowland grassland in the current study. The upland species may experience soil moisture deficit comparative to lowland as much of them were dominated by the grasses rather than legumes and in such cases, he low CP content could be expected (Seguin et al., 2002). The CP content being higher in the lowland north was unclear in comparison to lowland south but could be associated to the changes in soil nitrogen content. As expected, the soil mineral content variation between the grassland ecotypes might have acted on, which however limited the measurement in the present study. The change in $\mathrm{CP}$ content in the second harvest might be associated to the seasonal changes and developmental stage of herbages, however, the changes in herbage mass might be both affected by species diversity (Sanderson et al., 2004; Florine et al., 2006) and duration of growth, as well. The practical reason associated to high $\mathrm{CP}$ content at lowland north might be associated to the carryover effect of the continuous grazing (Pavlü et al., 2006) as a common phenomenon in the study sites and or rather high 
Journal of Agriculture and Natural Resources (2019) 1(1): 135-144

ISSN: 2661-6270 (Print), ISSN: 2661-6289 (Online)

DOI:https://doi.org/10.3126/janr.v2i1.26055

dominance of some leguminous and forbs species. However, to verify the carryover effect of the continuous stocking needs further verification by long term grazing experiments.

\section{CONCLUSIONS}

This study provides basic information on the variation of herbage $\mathrm{m}$ and proximate composition of range herbage available for livestock stall feeding and grazing as well in the Agriculture and Forestry livestock farm. Based on the findings of the study, it was concluded that studied grassland was rich in perennial grasses and sedges. The level of protein concentration of herbage was found below the animal requirements and that further suggests to incorporate legume pastures in the grasslands. The findings also revealed that the herbage productivity and composition differed with the grassland ecotypes and the research may further imply for the moisture availability and geographical aspect of the aspects.

\section{ACKNOWLEDGMENTS}

The authors are thankful to Agriculture and Forestry University (AFU) Animal nutrition lab for chemical analysis of the herbage samples. The contributions of Directorate of Research (DOR) of the Institute of Agriculture and Animal Science (IAAS), Tribhuvan University (TU) are highly acknowledged for funding as a small grant research project.

\section{Author contributions}

Prabin Pandey conducted the field experiment. Badrika Devkota-Barsila helped in data analysis. Shanker Raj Barsila designed the lab and field sampling protocols. Other co-authors involved in the manuscript revision and review.

\section{Conflict of Interest}

The authors declared no conflict of interest.

\section{REFERENCES}

AOAC (Association of Analytical Chemists).1990. Official method of analysis of AOAC international, 16 the ed. Method number 976.06., Arlington, VA, USA.

Austin, A. T. (2002). Differential effects of precipitation on production and decomposition along a rainfall gradient in Hawaii. Ecology, 83, 328-338.

Bailey, D.W., Gross, J.E., Laca, E.A., Rittenhouse, L.R., Coughenour, M.B., Swift, D.M. \& Sims, P.L. (1996). Mechanisms that result in large herbivore grazing distribution patterns. Journal of Range Management, 49, 386-400.

Baral, B. R., Adhikari, P., \& Shrestha, J. (2016). Productivity and economics of hybrid Maize (Zea mays L.) in the inner terai region of Nepal. Journal of AgriSearch, 3(1), 13-16.

Beecher, M., Henness, D., Boland, T.M., McEvoy, M., O'Donovan, M., \& Lewis, E. (2015). The variation in morphology of perennial ryegrass cultivars throughout the grazing season and effects on organic matter digestibility. Grass and Forage Science, 70, 1929.

Bennie, J., Hill, M.O., Baxter, R., \& Huntley, B. (2006). Influence of slope and aspect on long-term vegetation change in British chalk grasslands. Journal of Ecology, 94:355368. 
Journal of Agriculture and Natural Resources (2019) 1(1): 135-144

ISSN: 2661-6270 (Print), ISSN: 2661-6289 (Online)

DOI:https://doi.org/10.3126/janr.v2i1.26055

Cable, D. R. (1975). Influence of precipitation on perennial grass production in the semidesert southwest. Ecology, 56, 981-986.

Caldeira, M.C., Ryel, R.J., Laston, J.H. \& Pereira, J.S. (2001). Mechanisms of positive biodiversity-production relationships: Insights provided by $-\delta^{13} \mathrm{C}$ analysis in experimental Mediterranean grassland plots. Ecology Letters, 4, 439-443.

Chaudhary, S. \& Devkota, N.R. (2018). Determining chemical constituents of the selected rangeland to help improve feed quality under the context of climate change in the districts of Gandaki river basin. Journal of Agriculture and Forestry University, 2, 183-189.

Daly, M.J., Hunter, R.M., Green, G.N., \& Hunt, L. (1996). A comparison of multi-species pasture with ryegrass-white clover pasture under dryland conditions. Proceedings of New Zealand Grassland Association, 58, 53-58.

Fageria, N. K., Baligar, V. C. \& Jones, C. A. (2010). Growth and mineral nutrition of field crops. CRC Press.

Fay, P. A., Carlisle, J.D., Knapp, A.K., Blair, J.M. \& Collins, S.L. (2003). Productivity responses to altered rainfall patterns in a C 4-dominated grassland. Oecologia, 137, $245-251$.

Florine, S.E., Moore, K.J., Fales, S.L., White, T.A. \& Burras, C.L. (2006). Yield and composition of herbaceous biomass harvested from naturalized grassland in southern Iowa. Biomass and Bioenergy, 30, 522-528.

Fynn, R. W. S. \& O'connor, T.G. (2000). Effect of stocking rate and rainfall on rangeland dynamics and cattle performance in a semi-arid savanna, South Africa. Journal of Applied Ecology, 37, 491-507.

Gibbens, R.P. \& Beck, R.F. (1987). Increase in number of dominant plants and dominanceclasses on a grassland in the northern Chihuahuan Desert. Journal of Range Management, 40, 136-139.

Givens, D. I., Moss, A. R. \& Adamson, A. H. (1993). Influence of growth stage and season on the energy value of fresh herbage. 1. Changes in metabolizable energy content. Grass and Forage Science, 48, 166-174.

Jan, M. T., Shah, P., Hollington, P. A., Khan, M. J., \& Sohail, Q. (2009). Agriculture research: Design and analysis. A monograph. Peshawar Agricultural University.

Kandel, M., \& Shrestha J. (2019). Genotype x environment interaction and stability for grain yield and yield attributing traits of buckwheat (Fagopyrum tataricum Geartn). Syrian Journal of Agricultural Research, 6(3), 466-476.

LMP (Livestock Master Plan), 1993. Livestock Master Plan. The livestock Sector volume III, Asian Development Bank / ANZDECK/ APROSC.

NMRP. (2017). Annual Report of National Maize Research Program, Nepal Agricultural Research Council, Rampur, Chitwan, Nepal.

Pande, R.S. (2007). Grassland resources in Nepal. National Forage and Grassland Research Centre, Nepal.

Pariyar, D. (1993). Existing feed situation in different regions of Nepal and strategies developed to increase fodder production. Paper presented in the International Grassland Congress ISGR, 16-20. August. 1993. Hohehot, Inner Mongolia, P.R. of China. 
Journal of Agriculture and Natural Resources (2019) 1(1): 135-144

ISSN: 2661-6270 (Print), ISSN: 2661-6289 (Online)

DOI:https://doi.org/10.3126/janr.v2i1.26055

Pariyar, D., Banstola, B.R. \& Sedhain, G.K. (1998). Fodder and Pasture Research and Development in Nepal. Hills Leasehold Forestry and Forage Development Project, August 1996, Kathmandu.

Pavlů, V., Hejcman, M., Pavlů, L., Gaisler, J. \& Nežerková, P. (2006). Effect of continuous grazing on forage quality, quantity and animal performance. Agriculture, Ecosystem and Environment, 113, 349-355.

Payne, R. W., Harding, S.A. , Murray, D.A., Soutar, D.M., Baird, D.B., Glaser, A.I. \& Webster, R.(2008). GenStat release 11 reference manual, part 2 directives. VSN International, Hemel Hempstead, UK.

Radcliffe, J.E. (1982). Effects of aspect and topography on pasture production in hill country. New Zealand Journal of Agricultural Research, 25, 485-496.

Sanderson, M.A., Skinner, R.H., Barker, D.J., Edwards, G.R., Tracy, B.F. \& Wedin, D.A. (2004). Plant species diversity and management of temperate forage and grazing land ecosystems. Crop Science, 44, 1132-1144.

Sanderson, M.A., Soder, K.J., Muller, L.D., Klement, K.D., Skinner, R.H. \& Goslee, S.C. (2005). Forage mixture productivity and botanical composition in pastures grazed by dairy cattle. Agronomy Journal, 97, 1465-1471.

Seguin, P., Mustafa, A.F. \& Sheaffer, C.C. (2002). Effects of soil moisture deficit on forage quality, digestibility, and protein fractionation of Kura clover. Journal of Agronomy and Crop Science, 188, 260-266.

Sharma, H. P., Dhakal, K. H., Kharel, R. \& Shrestha, J. (2016). Estimation of heterosis in yield and yield attributing traits in single cross hybrids of maize. Journal of Maize Research and Development, 2(1), 123-132.

Shrestha, J. (2019). P-Value: A true test of significance in agricultural research. Retrieved from https://www.linkedin.com/pulse/p-value-test-significance-agricultural-researchjiban-shresthal

Snyman, H.A. \& Fouché, H.J. (1993). Estimating seasonal herbage production of a semi-arid grassland based on veld condition, rainfall, and evapotranspiration. African Journal of Range and Forage Science, 10, 21-24.

Tiwari M.R., Khanal, S.K., Shrestha, B.K. \& Jha, R.K. (2005). Nutritional values of grasses found in Nepal. Nepalese Veterinary Journal, 28, 78-94. 